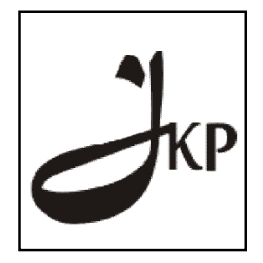

Jurnal Konseling dan Pendidikan

ISSN Cetak: 2337-6740 - ISSN Online: 2337-6880

http://jurnal.konselingindonesia.com

Volume 3 Nomor 3, November 2015, HIm 8-12

Info Artikel:

Diterima 07/10/2015

Direvisi 07/11/2015

Dipublikasikan 28/11/2015

\title{
METODE UMPAN BALIKUNTUK MENINGKATKAN HASIL BELAJAR SISWA PADA MATA PELAJARAN PENDIDIKAN AGAMA ISLAM ( PAI) DI KELAS III SD NEGERI 45 PULAU KARAM KECAMATAN KOTO XI TARUSAN
}

ALMI

Abstrak

Hasil belajar siswa pada mata pelajaran Pendidikan Agama Islam ( PAI) di SD Negeri 45 Pulau Karam Kecamatan Koto XI Tarusanmasih rendah. Hal tersebut disebabkan metode pembelajaran yang selama ini diterapkan kurang efektif untuk meningkatkan hasil belajar siswa.Salah satu metode pembelajaran yang dapat digunakan dalam pembelajaran PAI adalah umpan balik. Tujuan penelitian ini untuk mendapatkan gambaran tentang penerapan metode umpan balik pada pembelajaran PAI di kelas III SD Negeri 45 Pulau Karam Kecamatan Koto XI Tarusan.Penelitian ini menggunakan metode penelitian tindakan kelas yang ditempuh dalam dua siklus. Subjek penelitian adalah siswa SD Negeri 45 Pulau Karam Kecamatan Koto XI Tarusanyang terdiri dari 22 siswa.Hasil penelitian memperlihatkan bahwa melalui Metodeumpan balik, kemampuan siswa dalam menyampaikan materi di depan kelas dan belajar mandiri di rumah dapat ditingkatkan. Selain itu siswa menjadi lebih berani mengemukakan pendapat dan dapat menerapkan Pendidikan Agama Islam ( PAI )dalam kehidupan bermasyarakat.

Keyword: metode umpan balik, pembelajaran PAI dan siswa SD

Copyright (C) 2015 IICET (Padang - Indonesia) - All Rights Reserved

Indonesian Institute for Counseling, Education and Theraphy (IICET)

\section{PENDAHULUAN}

Potensi sumber daya manusia pada hakikatnya adalah salah satu modal dasar pembangunan nasional. Namun selama ini masih dirasakan bahwa potensi sumber daya manusia tersebut belum dapat dimanfaatkan secara optimal mengingat sebagian besar dari angkatan kerja, tingkat keterampilan dan pendidikannya masih rendah. Rendahnya pendidikan akan sangat berpengaruh besar terhadap sikap mental tenaga kerja yang berakibat rendahnya unjuk kerja. Untuk mendapatkan sumber daya manusia potensial dibutuhkan kelembagaan pendidikan yang tangguh. Lembaga pendidikan yang dapat memberikan bekal kepada siswa dalam mengembangkan kehidupan mereka sebagai pribadi, anggota masyarakat, warga negara dan mempersiapkannya untuk mengikuti pendidikan selanjutnya. Adanya keinginan untuk meningkatkan kualitas diri sesuai nilai dan norma yang berlaku di lingkungan, diperlukan peningkatan pendidikan.

Perubahan kurikulum diperlukan untuk mencapai tujuan tersebut.Perubahan kurikulum disesuaikan dengan perkembangan dan kemajuan zaman seperti penerapan kurikulum 2006 atau Kurikulum Tingkat Satuan Pendidikan (KTSP). KTSP berisi tentang seperangkat rencana dan pengaturan tentang kompetensi yang dibakukan untuk mencapai tujuan nasional dan cara penerapannya disesuaikan dengan keadaan dan kemampuan daerah, serta Sekolah (Depdiknas: 2006). Kompetensi adalah "Pengetahuan, keterampilan dan nilai-nilai dasar yang direfleksikandalam kebiasaan berfikir dan bertindak, dalam arti memiliki pengetahuan keterampilan dan nilai-nilai dasar untuk melakukan sesuatu" (Depdiknas:2006:2). Guru merupakan kunci dalam meningkatkan mutu pendidikan. Mereka berada pada titik sentral dari setiap usaha reformasi pendidikan seperti pengembangan metode-metode mengajar, penyediaan sarana dan prasarana.

Guru di Sekolah Dasar(SD) mengajar berbagai bidang studi, diantaranya Pendidikan Agama Islam.Pembelajaran yang dilaksanakan di dalam kelas lebih didominasi oleh guru sehingga siswa menjadi pasif dan membuat mereka menjadi bosan.Penggunaan media yang belum memadai sehingga pembelajaran tidak menarik bagi siswa.Siswa hanya hanya menjadi pendengar,penulis ringkasan atau pencatat materi yang ada pada buku sumber. 
Penggunaan metode umpan balik merupakan salah satu solusi dari permasalahan pembelajaran untuk meningkatkan hasil belajar siswa pada mata pelajaran PAI kelas III.Umpan balik dalam proses pembelajaran yang dilaksanakan dengan konsisten dapat meningkatkan prestasi belajar siswa.Setiap anak didik mempunyai motivasi belajar yang berbeda-beda. Oleh karena itu, setiap guru dituntut untuk memahami hal ini agar pembelajaran yang dilaksanakan tidak asal-asalan. Guru yang mengabaikan perbedaan motivasi dalam diri setiap anak didik cenderung mengalami kegagalan dalam melaksankan tugasnya mengajar di kelas (Syaiful Bahri D dan Aswan Zain, 2006:142).Dengan umpan balik dimaksudkan bahwa guru dan siswa menciptakan suasana pembelajaran yang aktif, kreatif dan menyenangkan. Guru dapat merangsang siswa agar lebih aktif dalam pembelajaran. Umpan balik yang efektif merupakan bagian integral dari sebuah dialog instruksional antara guru dengan siswa, siswa dengan siswa, maupun siswa dengan dirinya sendiri, dan bukanlah sebuah praktik yang terpisahkan (Sudrajat,A: 2009 dan Winata Putra: 2003).

Berdasarkan penjelasan sebelumnya perlu dilakukan penelitian dengan rumusan masalahnya yaitu bagaimanakah deskripsi pembelajaran menggunakan metode umpan balik untuk meningkatkan hasil belajar siswa pada mata pelajaran Pendidikan Agama Islam (PAI) di Kelas III SD Negeri 45 Pulau Karam Kecamatan Koto XI Tarusan.Tujuan penelitian ini untuk mendapatkan gambaran tentang pelaksanaan pembelajaran menggunakan metode umpan balik untuk meningkatkan hasil belajar siswa pada mata pelajaran Pendidikan Agama Islam (PAI) di Kelas III SD Negeri 45 Pulau Karam Kecamatan Koto XI Tarusan.

\section{METODOLOGI PENELITIAN}

Penelitian ini menggunakan pendekatan tindakan kelas.Penelitian tindakan kelas dilaksanakan dalam dua siklus. Pelaksanaan penelitian dari tanggal 28 September 2014 sampai dengan tanggal 5 Oktober 2014. Penelitian tindakan kelas menggunakan langkah-langkah penelitian yang disampaikan oleh Suharsimi Arikunto (2007:16)dan Wardani (2004) yang terdiri dari empat langkah yaitu: perencanaan, pelaksanaan tindakan, observasi/pengamatan, dan refleksi.Materi yang digunakan pada penelitian ini adalah mengenal sifat-sifat Allah SWT.Subjek penelitian ini adalah siswa kelas III SDN 45 Pulau Karam Kecamatan Koto XI Tarusan Kab. Pesisir Selatan.

Pembelajaran dengan menggunakan metode umpan balik harus direncanakan dengan baik.Kegiatan yang dilakukan sebelum membuat RPP berikut ini.

1. Menemukan masalah yang akan diselesaikan.

2. Penyusunan materi pelajaran secara sistematis.

3. Membuat RPP

4. Membuat instrumen penilaian.

Sesuai dengan masalah yang dihadapi yaitu banyaknya siswa yang memperoleh nilai rendah dan tidak dapat menjawab pertanyaan yang diajukan oleh guru. Maka beberapa kegiatan khusus yang dapat perhatian dalam perbaikan mata pelajaran PAI adalah pemberian tugas dengan pendekatan keterampilan proses.

\section{HASIL DAN PEMBAHASAN PENELITIAN HASIL PENELITIAN \\ Perencanaan \\ Siklus I}

a. Mengkondisikan siswa agar siap mengikuti pembelajaran.

b. Menyampaikan materi pelajaran secara runtut dan jelas.

c. Membahas materi pelajaran dengan menggunakan metode umpan balik

d. Menyimpulkan materi pelajaran.

e. Memberikan tugas dan pekerjaan rumah sebagai pengayaan materi yang telah diajarkan.

\section{Siklus II}

Perbaikan yang dilakukan pada siklus II

a. Memperlihatkan gambar-gambar / chart yang disiapkan sebagai alat memotivasi siswa.

b. Menjelaskan materi dengan menggunakan alat peraga dan metode umpan balik.

c. Menyimpulkan materi dan menuliskan hal-hal penting.

d. Memberikan tugas cerita individu / pekerjaan rumah. 


\section{Pelaksanaan}

Pelaksanaan pembelajaran sudah sesuai yang direncanakan, baik pada siklus I maupun siklus II.Perbedaan pelaksanaan pembelajaran pada siklus I dan II terletak pada penggunaan media pembelajaran.Saat memotivasi siswa di awal pembelajaran guru memperlihatkan gambar yang menarik.Saat menggunakan metode umpan balik, guru menambahkan dengan menggunakan alat peraga.Saat menyimpulkan materi pembelajaran guru menuliskannya di papan tulis agar siswa dapat mengetahui intisari materi yang dipelajari.Bentuk tugas pengayaan juga diubah dengan memberikan tugas cerita yang diselesaikan secara individu.

\section{Observasi/Pengamatan}

Hasil observasi terhadap nilai rata-rata yang diperoleh siswa kelas III SD Negeri 45 Pulau Karam Kecamatan Koto XI Tarusan, pada mata pelajaran PAI sebagai berikut:

\section{Tabel 1}

Rekapitulasi Hasil Belajar Siswa Kelas III

\begin{tabular}{|c|c|c|c|c|}
\hline \multirow[b]{3}{*}{ NO } & \multirow{3}{*}{ NAMA SISWA } & \multicolumn{3}{|c|}{ N I L A I } \\
\hline & & \multirow{2}{*}{ Pra Sikus } & \multicolumn{2}{|c|}{ Sesudah perbaikan } \\
\hline & & & Siklus I & Siklus II \\
\hline 1 & $\mathrm{Ha}$ & 4 & 8 & 9 \\
\hline 2 & An & 5 & 8 & 8.3 \\
\hline 3 & $\mathrm{DH}$ & 4 & 6 & 8 \\
\hline 4 & UR & 4 & 6 & 7.5 \\
\hline 5 & A. J & 7 & 7 & 7.5 \\
\hline 6 & $\mathrm{MeL}$ & 4 & 6 & 7.5 \\
\hline 7 & $\mathrm{HS}$ & 5 & 6 & 8.5 \\
\hline 8 & NA & 7 & 7 & 8 \\
\hline 9 & MA & 5 & 6 & 9 \\
\hline 10 & $\mathrm{Yu}$ & 5 & 7 & 8 \\
\hline 11 & ARJ & 5 & 6 & 7.5 \\
\hline 12 & $\mathrm{IH}$ & 5 & 6 & 7 \\
\hline 13 & NK & 5 & 8 & 8 \\
\hline 14 & $\mathrm{RD}$ & 4 & 5 & 7.5 \\
\hline 15 & SK & 3 & 6 & 8 \\
\hline 16 & $\mathrm{TS}$ & 5 & 5 & 8.5 \\
\hline 17 & YS & 8 & 8 & 9 \\
\hline 18 & M.H & 4 & 6 & 8 \\
\hline 19 & $\mathrm{NII}$ & 7 & 7 & 7.5 \\
\hline 20 & $\mathrm{TH}$ & 6 & 6 & 8 \\
\hline 21 & $\mathrm{MF}$ & 7 & 7 & 8 \\
\hline & JUMLAH & 114 & 142 & 176 \\
\hline & RATA-RATA & 5.18 & 6.45 & 7.99 \\
\hline
\end{tabular}

Hasil belajar siswa ini menunjukkan terjadinya peningkatan. Rata-rata hasil belajar sebelum dilaksanakan penelitian sebesar 5,18. Pada siklus I dilaksanakan pembelajaran dengan metode umpan balik, hasil yang didapat diketahui bahwa terjadi peningkatan hasil belajar siswa dengan rata-rata 6,45. Pada siklus II terjadi peningkatan hasil belajar siswa menjadi rata-rata 7,99. Hal ini terjadi karena dilakukan perbaikan dalam proses pembelajaran.Berdasarkan hasil diskusi dengan teman sejawat dan supervisor pembelajaran yang dilaksanakan telah menunjukan suatu peningkatan dari $23.5 \%$ menjadi $36.32 \%$ untuk mata pelajaran PAI. Hal ini terlihat dari 
adanya peningkatan nilai rata-rata tes formatif dalam pelajaran PAI kelas III.Hasil pengamatan supervisor secara kuantitas adalah sebagai Terdapat 10 siswa yang dapat menjawab pertanyaan dari guru.

Refleksi

Terdapat perbaikan dalam pembelajaranyang dilaksanakan yaitu :Perbaikan yang terkait dalam pembelajaran PAI adalah Penggunaan metode umpan balik diselingi dengan alat peraga yang sesuai. Saat menyimpulkan materi pembelajaran, guru mencatat dipapan tulis agar siswa dapat melihat/mengetahui konsep yang diajarkan.Pekerjaan rumah diberikan guru secara individu, agar siswa lebih memahami materi tentang sifatsifat Allah SWT.

\section{PEMBAHASAN PENELITIAN}

Setelah adanya perbaikan terlihat perubahan nilai yang signifikan dari nilai rata-rata siswa kelas III dari rata-rata 5,18 menjadi 7,99 atau semula 6 orang siswa atau 27,2\% yang mampu menguasai materi $60 \%$ keatas, sesudah perbaikan ada 14 orang siswa atau $63.6 \%$ yang mampu menguasai materi pelajaran diatas $75 \%$. Siswa yang telah menjalani proses belajarakan terjadi perubahan dalam dirinya. Apabila sebelum menjalani proses belajar seseorang belum mempunyai pengetahuan akan sesuatu hal dan belum mepunyai keterampilan tertentu dan bersikap tidak menolak pada infomasi yang diberikan, maka setelah menjalani proses belajar Ia akan menjadi tahu atau lebih tahu, dan menjadi terampil atau lebih terampil.

Proses perubahan yang terjadi harus relative bersifat menetapkan tidak terjadi hanya pada saat ini yang tampak, tetapi juga pada perilaku yang mungkin terjadi pada masa mendatang.Proses belajar mengajar pada mata pelajaran PAI, guru hendaknya menyampaikan atau mengalihkan pesan atau pengetahuan yang diyakini berguna bagi siswa dikemudian hari untuk dipelajari dan difahami(Kuraesin, 2004). Guru membahas materi pembelajaran dapat dilakukan secara efektif agar siswa dapat memahami atau mempelajari materi yang disampaikan, serta memberikan umpan balik mengenaiperkembangan proses belajar yang dijalani siswa(Rukmana dan Suryana,

2006: 13). Dari sisi siswa juga diharapkan agar mereka dapat menyampaikan informasi kepada guru bah wa materi yang disampaikan guru, tidak atau belum dapat difahami atau dimengerti, sehingga dapat dilakukan pengulangan proses belajar.

\section{KESIMPULAN DAN SARAN KESIMPULAN}

Berdasarkan hasil penelitian tindakan kelas yang telah dilaksanakan pada pembelajaran PAI kelas III dengan menggunakan metode umpan balik, maka dapat ditarik kesimpulan bahwa penggunaan metode umpan balik dalam pembelajaran PAI di kelas III dan dapat meningkatkan hasil belajar siswa. Hal ini dibuktikan dari nilai rata-rata hasil tes formatif, pada mata pelajaran PAI di kelas III diperoleh nilai pra siklus 5.18, siklus I 6.45 dan siklus II 7.99 terlihat ada peningkatan yang signifikan dari setiap siklusnya.

Penggunaan metode umpan balik dalam pembelajaran PAI di sekolah dasar dapat merangsang siswa untuk memahami dan menemukan pemecahan masalah yang ditemuinya selama proses pembelajaran, menemukan ide dan gagasan baru dalam memodifikasi keadaaan yang disaksikan langsung, menumbuhkan sifat kritis yang dinyatakan dalam wujud kemauan bertanya dan mengemukakan pendapat serta melatih keterampilan siswa dalam mengkomunkasikan hasil suatu kegiatan baik secara lisan maupun secara tertulis.

Dengan kata lain, penggunaan metode umpan balik dalam pembelajaran lebih meningkatkan kemampuan pemahaman siswa, mengefektifkan pencapaian tujuan, baik tujuan secara umum maupun khusus dan meningkatkan hasil belajar siswa.

\section{SARAN}

Berdasarkan hasil penelitian dalam pembelajaran PAI dengan menggunakan metode umpan balik, maka peneliti dapat merekomendasikan hal-hal sebagai berikut :

\section{Guru}

Hendaknya guru menggunakan metode umpan balik dalam pembelajaran PAI, untuk meningkatkan kemampuan guru dan siswa dalam pembelajaran, dan menjadikan acuan untuk menajdi guru yang prodesional, dan juga hendaknya dalam setiap materi disertakan alat peraga agar tidak terjadi verbalisme. 


\section{Kepala Sekolah}

Kepala Sekolah dapat menjadikan penggunaan metode umpan balik sebagai bahan pembinaan profesional bagi guru-guru dalam rangka peningkatan mutu pembelajaran PAI di kelas.

\section{Pengawas}

Salah satu tugas pengawas adalah memberikan pengarahan kepada guru-guru dalam kegiatan pembelajaran, maka untuk itu dalam mengarahkan para guru dalam satu gugus tersebut untuk mencoba menerapkan metode edan pendekatan yang bervariasi dalam kegiatan pembelajaran PAI untuk meningkatkan kemampuan siswa dalam memahami materi pembelajaran, karena hal ini telah berhasil seperti yang telah dilakukan oleh peneliti.

\section{DAFTAR PUSTAKA}

Depdiknas.2006.Kurikukum Tingkat Satuan Pendidikan Sekolah Dasar Dan Madrasah Ibtidaiyah, Jakarta: CV. Timur Putra Mandiri.

Djamarah, S.B. dan Zain Aswan.(2006). Strategi Belajar Mengajar. Jakarta: PT. Rineka Cipta.

Kuraesin, E. (2004). Belajar PAI Untuk Siswa SD. Bandung: PT. Sarana Panca Karya Nusa.

Rukmana, A dan Suryana, A. (2006).Pengelolaan Kelas. Bandung: UPI PRESS.

Rahman.A. (2009).PAI Kelas V. Solo : Indonesia Jaya.

Sudrajat, A. (2009). Umpan Balik Yang Efektif Bagi Siswa. [Online].Tersedia: http://akhmadsudrajat.wordpress.com/2009/10/12/umpan-balik-yang-efektif-bagi-siswa Suharsimi Arikunto. 2007. Penelitian Tindakan Kelas. Jakarta: Bumi Aksara.

Wardani I. G. A. K, dkk.2004.Penelitian Tindakan Kelas.Jakarta : Universitas Terbuka

Winataputra Udin S. 2003. Materi Pokok Strategi Belajar Mengajar. Jakarta : Universitas Terbuka. 